\title{
Extracellular DNA: A Nutritional Trigger of Mycoplasma bovis Cytotoxicity
}

\author{
Xifang Zhu ${ }^{1,2,3,4}$, Emilie Dordet-Frisoni ${ }^{5}$, Lucie Gillard ${ }^{5}$, Abou Ba ${ }^{5}$,

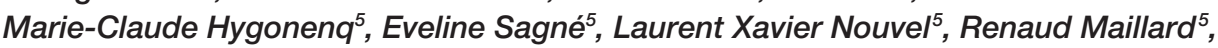 \\ Sébastien Assié ${ }^{,}$Aizhen Guo ${ }^{1,2,3,4}$, Christine Citti ${ }^{5}$ and Eric Baranowski ${ }^{5 *}$ \\ 'The State Key Laboratory of Agricultural Microbiology, College of Veterinary Medicine, Huazhong Agricultural University, \\ Wuhan, China, ${ }^{2}$ Hubei International Scientific and Technological Cooperation Base of Veterinary Epidemiology, International \\ Research Center for Animal Disease, Ministry of Science and Technology of China, Wuhan, China, ${ }^{3}$ Key Laboratory of \\ Preventive Veterinary Medicine in Hubei Province, The Cooperative Innovation Center for Sustainable Pig Production, \\ Wuhan, China, ${ }^{4}$ Key Laboratory of Development of Veterinary Diagnostic Products, Key Laboratory of Ruminant \\ Bio-products, Ministry of Agriculture and Rural Affairs of China, Wuhan, China, ${ }^{5}$ IHAP, ENVT, INRA, Université de Toulouse, \\ Toulouse, France, ${ }^{6}$ BioEpAR, INRA, Oniris, Nantes, France
}

\section{OPEN ACCESS}

Edited by: Mattias Collin,

Lund University, Sweden

Reviewed by: Steven M. Szczepanek, University of Connecticut, United States

Lucas Miranda Marques, Federal University of Bahia, Brazil

${ }^{*}$ Correspondence:

Eric Baranowski

eric.baranowski@envt.fr

Specialty section: This article was submitted to Infectious Diseases,

a section of the journal

Frontiers in Microbiology

Received: 13 August 2019 Accepted: 12 November 2019 Published: 29 November 2019

Citation:

Zhu X, Dordet-Frisoni E, Gillard L, $B a A$, Hygonenq M-C, Sagné E, Nouvel LX, Maillard R, Assié S, Guo A, Citti $C$ and Baranowski E (2019) Extracellular DNA:

A Nutritional Trigger of Mycoplasma bovis Cytotoxicity. Front. Microbiol. 10:2753. doi: 10.3389/fmicb.2019.02753
Microbial access to host nutrients is a key factor of the host-pathogen interplay. With their nearly minimal genome, wall-less bacteria of the class Mollicutes have limited metabolic capacities and largely depend on host nutrients for their survival. Despite these limitations, host-restricted mycoplasmas are widely distributed in nature and many species are pathogenic for humans and animals. Yet, only partial information is available regarding the mechanisms evolved by these minimal pathogens to meet their nutrients and the contribution of these mechanisms to virulence. By using the ruminant pathogen Mycoplasma bovis as a model system, extracellular DNA (eDNA) was identified as a limiting nutrient for mycoplasma proliferation under cell culture conditions. Remarkably, the growth-promoting effect induced by supplementation with eDNA was associated with important cytotoxicity for actively dividing host cells, but not confluent monolayers. To identify biological functions mediating $M$. bovis cytotoxicity, we produced a library of transposon knockout mutants and identified three critical genomic regions whose disruption was associated with a non-cytopathic phenotype. The coding sequences (CDS) disrupted in these regions pointed towards pyruvate metabolism as contributing to $M$. bovis cytotoxicity. Hydrogen peroxide was found responsible for eDNA-mediated $M$. bovis cytotoxicity, and non-cytopathic mutants were unable to produce this toxic metabolic compound. In our experimental conditions, no contact between $M$. bovis and host cells was required for cytotoxicity. Further analyses revealed important intra-species differences in eDNA-mediated cytotoxicity and $\mathrm{H}_{2} \mathrm{O}_{2}$ production, with some strains displaying a cytopathic phenotype despite no $\mathrm{H}_{2} \mathrm{O}_{2}$ production. Interestingly, the genome of strains PG45 and HB0801 were characterized by the occurrence of insertion sequences (IS) at close proximity to several CDSs found disrupted in non-cytopathic mutants. Since PG45 and $\mathrm{HB} 0801$ produced no or limited amount of $\mathrm{H}_{2} \mathrm{O}_{2}$, IS-elements might influence $\mathrm{H}_{2} \mathrm{O}_{2}$ production in $\mathrm{M}$. bovis. These results confirm the multifaceted role of eDNA in microbial 


\begin{abstract}
communities and further identify this ubiquitous material as a nutritional trigger of $M$. bovis cytotoxicity. M. bovis may thus take advantage of the multiple sources of eDNA in vivo to modulate its interaction with host cells, a way for this minimal pathogen to overcome its limited coding capacity.
\end{abstract}

Keywords: Mycoplasmas bovis, extracellular DNA, cytotoxicity, hydrogen peroxide, pyruvate metabolism, virulence factors

\section{INTRODUCTION}

Beyond its role as universal support of genetic information, DNA is emerging as a multifaceted macromolecule with broad implications for microbial physiology and host defenses (Vorkapic et al., 2016; Gallucci and Maffei, 2017; Ibáñez de Aldecoa et al., 2017; Nagler et al., 2018). These novel properties are mainly attributed to extracellular DNA (eDNA), a ubiquitous material of prokaryotic and eukaryotic origin that can be isolated from a wide range of natural environments including biological fluids (Vlassov et al., 2007; Vorkapic et al., 2016; Aucamp et al., 2018; Nagler et al., 2018).

As a source of genetic information, eDNA contributes to bacterial genome maintenance and evolution (Mell and Redfield, 2014; Blokesch, 2017). Naturally competent bacteria are able to actively transport eDNA fragments across their cell envelope. This incoming genetic information can be used to repair damaged DNA, delete selfish mobile genetic elements, or acquire new phenotypic traits. As a biopolymer, eDNA is a structural component of biofilms (Das et al., 2013; Okshevsky and Meyer, 2015; Vorkapic et al., 2016; Ibáñez de Aldecoa et al., 2017; Nagler et al., 2018). Another important aspect of eDNA is its function as a source of nutrients (Vorkapic et al., 2016; Ibáñez de Aldecoa et al., 2017). Several bacteria use extracellular nucleases to degrade eDNA, whereas others use competence genes, or competence gene homologs, to uptake eDNA under nutritional stress.

Mycoplasmas are members of the class Mollicutes, a large group of wall-less bacteria that are well known for having some of the smallest genomes thus far characterized in freeliving organisms (Citti and Blanchard, 2013). As such, mycoplasmas lack a significant number of biological functions found in more classical bacteria and have important nutritional requirements (Razin et al., 1998; Pereyre et al., 2009; Masukagami et al., 2017). Despite these limitations, mycoplasmas are widely distributed in nature where they live in close association with their hosts, with many species being successful human or animal pathogens. The control of these organisms is facing an alarming rate of drug resistance and a lack of effective vaccines causing growing concerns both in the medical and veterinary fields (Citti and Blanchard, 2013; Gautier-Bouchardon, 2018; Kirby, 2018). Among those, Mycoplasma bovis is emerging worldwide as a major cause of pneumonia and mastitis in cattle and is an important economic burden for the livestock industry (Bürki et al., 2015; Lysnyansky and Ayling, 2016; Nicholas and Ayling, 2016; Perez-Casal et al., 2017).

Mycoplasmas are recurrently found associated with cultures of mammalian cells, where they can survive for long periods, often without apparent signs of contamination. Yet, several pathogenic species are able to induce cellular vacuolization or a pronounced cytopathic effect (Rottem, 2003; Kannan and Baseman, 2006; Hegde et al., 2016; Josi et al., 2018). However, factors contributing to host cell damages are still poorly understood. The main reason is that mycoplasmas are lacking the classical repertoire of virulence genes found in more complex bacteria. Indeed, the only example of mycoplasma products exhibiting classical toxin-like activities is the ADP-ribosylating and vacuolating cytotoxin of the human pathogen Mycoplasma pneumoniae (Kannan and Baseman, 2006). The development of axenic and cell culture conditions together with the construction of specific tools for their genetic manipulation has greatly facilitated the study of these fastidious organisms. These advances have largely contributed not only to a better understanding of the remarkable plasticity of their surface architecture (Citti et al., 2010) but also to the discovery of massive horizontal gene transfers within and across species (Citti et al., 2018).

Despite their complex nutritional requirement, the mechanisms evolved by mycoplasmas to access nutrients essential for their multiplication in vivo are poorly understood. Nucleic acids are long known for influencing the proliferation of several fastidious mycoplasma species under axenic growth conditions (Razin and Knight, 1960). However, the role of eDNA in the infectious process of pathogenic species has never been addressed. In the present study, eDNA was identified as a limiting nutrient for mycoplasma proliferation in cell culture conditions, using the ruminant pathogen Mycoplasma bovis as a model system. The growth-promoting effect of eDNA on $M$. bovis was associated with important cytotoxicity for actively dividing cells, an event mediated by the release of $\mathrm{H}_{2} \mathrm{O}_{2}$ in the culture medium.

\section{MATERIALS AND METHODS}

\section{Mycoplasmas, Cell Lines, and Culture Conditions}

$M$. bovis strains and colony-purified isolates used in the present study are described in Table 1. Mycoplasmas were grown at $37^{\circ} \mathrm{C}$ in SP4 medium supplemented with $45 \mu \mathrm{g} / \mathrm{ml}$ cefquinome (Cobactan, MSD Animal Health). Gentamicin $(50 \mu \mathrm{g} / \mathrm{ml})$ was added to the media for the propagation of $M$. bovis mutants generated by transposon mutagenesis. Mycoplasma titers were determined based on colony counts on solid media after 3-5 days of incubation at $37^{\circ} \mathrm{C}$. The embryonic bovine lung (EBL) cell line was kindly provided by M. Heller (Friedrich-Loeffler-Institute, Jena, Germany). Cells were grown in DMEM-based medium 
TABLE 1 | M. bovis type and field strains used in the present study.

\begin{tabular}{|c|c|c|c|c|c|}
\hline Strain $^{a}$ & Origin & Year of isolation & Host & Clinical manifestations & Reference \\
\hline PG45 & USA & 1962 & Bovine & Mastitis & Wise et al. (2011) \\
\hline HB0801 & China & 2008 & Bovine & Respiratory & Qi et al. (2012) \\
\hline HB0801 P150 & China & 2008 & Bovine & Respiratory & Zhang et al. (2014) \\
\hline RM16 & France & 2016 & Bovine & Respiratory & This study \\
\hline 1067 & France & 1983 & Bovine & Mastitis & Le Grand et al. (2002) \\
\hline 7103 & France & 2016 & Bovine & Respiratory & This study \\
\hline 4785 & France & 1990 & unknown & Respiratory & Marenda et al. (2005) \\
\hline 8790 & Ethiopia & 1987 & Caprine & Respiratory & Manso-Silván et al. (2012) \\
\hline SA1 & France & 2004 & Bovine & Respiratory & This study \\
\hline SA2 & France & 2004 & Bovine & Respiratory & This study \\
\hline SA5 & France & 2005 & Bovine & Respiratory & This study \\
\hline SA7 & France & 2006 & Bovine & Respiratory & This study \\
\hline
\end{tabular}

${ }^{a} M$. bovis strain HB0801 P150 was selected by 150 serial passages of the virulent strain HB0801. Whole-genome sequences of strains PG45, HB0801, and HB0801 P150 are available in databanks with accession numbers NC_014760.1/CP002188.1, NC_018077.1/CP002058.1, and NZ_CP007590.1/CP007590.1, respectively. Draft genome sequences of strains 1067 and 8790 are available as whole-genome shotgun projects with accession numbers LAUT01 and LAUSO1, respectively. RM16, SA1, SA2, SA5, SA7 are colonypurified isolates originating from the French department number 15 (Cantal; RM16), 44 (Loire-Atlantique; SA1, SA2, SA7), and 85 (Vendée; SA5). SA1 and SA2 were isolated from the same animal (SA1, transtracheal aspirate; SA2, lung sample). These isolates were originaly named as 415 MAE 04 (SA1 and SA2), 413 MAE 05 (SA5), and 453 MAE 06 (SA7).

consisting of Dulbecco's modified Eagle's medium (DMEM, high glucose, sodium pyruvate, and GlutaMAX-I; Gibco) supplemented with non-essential amino acids (NEAA, Gibco) and 10\% heatinactivated fetal bovine serum (FBS, Gibco). The mycoplasmafree status of the cell line was tested by using a genus-specific PCR (van Kuppeveld et al., 1992).

\section{Co-cultivation of $M$. bovis With Bovine Lung Cells and Crystal Violet Cell Cytotoxicity Assay}

M. bovis and EBL cells were co-cultivated in DMEM-based medium, as previously described (Baranowski et al., 2010). Briefly, EBL cells were seeded in 24-well plates (Falcon) at a density of $5 \times 10^{3}$ cells $/ \mathrm{cm}^{2}$ and inoculated with $M$. bovis at multiplicity of infection (MOI) of 2. Since SP4 medium (up to $0.1 \%$ ) has no apparent toxic effect on EBL cells (data not shown), M. bovis inoculums were prepared by direct dilution of mycoplasma stock cultures with predefined titers in DMEMbased medium. At different time post-inoculation, mycoplasma titers were determined by CFU titration following one freezethaw cycle. Mycoplasma cytotoxicity was determined by staining cell monolayers with crystal violet. Cell monolayers were washed with Dulbecco's phosphate-buffered saline (DPBS, Gibco) and stained for $60 \mathrm{~min}$ with $0.1 \%$ crystal violet solution in $10 \%$ ethanol. After washing with water, plates were air-dried and incubated with $95 \%$ ethanol for $2 \mathrm{~h}$ at room temperature before measuring the optical density at $590 \mathrm{~nm}$.

To test the influence of extracellular nucleic acids on M. bovis cytotoxicity, mycoplasmas and EBL cells were co-cultivated in DMEM-based medium supplemented with increasing concentration of calf thymus DNA (UltraPure ${ }^{\mathrm{TM}}$ Calf Thymus DNA Solution, Invitrogen) and/or yeast tRNA (Invitrogen). Calf thymus DNA treatment with Proteinase K (Qiagen), DNase I (Invitrogen), and RNase A (Invitrogen) was performed by $1 \mathrm{~h}$ incubation in DMEM medium and 15 min heating at $96^{\circ} \mathrm{C}$. Polynucleotides were removed from DNase I digestion products by using the QIAquick PCR Purification Kit (Qiagen).
To test the cytotoxicity of cell culture supernatants infected with $M$. bovis, mycoplasma cells were killed by a gentamicin treatment $(400 \mu \mathrm{g} / \mathrm{ml})$ for $3 \mathrm{~h}$ at $37^{\circ} \mathrm{C}$ and mycoplasma cells were depleted by $30 \mathrm{~min}$ centrifugation at $12,000 \times g\left(4^{\circ} \mathrm{C}\right)$. These treated supernatants were then applied to EBL cells $\left(5 \times 10^{3}\right.$ cells $\left./ \mathrm{cm}^{2}\right)$ for $72 \mathrm{~h}$, and cytotoxicity was measured by crystal violet staining. Catalase from bovine liver (Sigma) was used to remove $\mathrm{H}_{2} \mathrm{O}_{2}$ from cell culture supernatants $(60 \mathrm{U} / \mathrm{ml}$; $2 \mathrm{~h}$ incubation at room temperature).

\section{Random Transposon Mutagenesis in M. bovis}

Transposon mutagenesis was carried out by using plasmid pMT85, as previously described (Baranowski et al., 2010). Plasmid pMT85, which contains a modified version of Tn4001 (mTn) was kindly provided by Richard Herrmann (Zimmerman and Herrmann, 2005). Briefly, gentamicin-resistant colonies were collected from 18 independent transformations and grown in $1 \mathrm{ml}$ of selective SP4 medium. Individual mutants were distributed in 96-well plates and stored at $-80^{\circ} \mathrm{C}$. Transposon insertion sites in the $M$. bovis chromosome were mapped by sequencing the junction between mycoplasma genomic DNA and the mTn. Briefly, $M$. bovis mutants were amplified by single-primer PCR (Karlyshev et al., 2000) using oligonucleotide primers SG6pMT85 (CGGAAACCAGGCAACGAC) or SG8pMT85 (GAGTCAGTGAG CGAGGAAGC) and the following annealing temperatures: 55 (20 cycles), 30 (30 cycles), and $55^{\circ} \mathrm{C}$ (30 cycles). The PCR products were sequenced with the nested primers SG6-2 (GCCGCGTCAATTGGTGGGGT), SG6-3 (ACGGCCGATGA ATCCTCTA) or EB8 (GGAAGAGCGCCCAATACGCA) (Eurofins Genomics).

\section{Identification of $M$. bovis Mutants With Reduced Cytotoxicity}

M. bovis mutants displaying reduced cytotoxicity for EBL cells were selected from the mutant library by high-throughput screening in 96-well plates (Falcon). EBL cells were seeded at 
a density of $5 \times 10^{3}$ cells $/ \mathrm{cm}^{2}$ in DMEM-based medium supplemented with $10 \mu \mathrm{g} / \mathrm{ml}$ calf thymus DNA (Invitrogen) and inoculated with individual mutants using the 96-pin replicator (Boekel Scientific). After 3 days of co-cultivation, cells were stained with crystal violet (see above) and $M$. bovis mutants displaying reduced cytotoxicity were selected by visualization of the cytopathic effect. The non-cytotoxic phenotype of the selected mutants was confirmed by a second co-cultivation with EBL cells in larger 24-well plates (Falcon).

\section{Quantification of Hydrogen Peroxide Production}

The production of $\mathrm{H}_{2} \mathrm{O}_{2}$ by $M$. bovis was estimated by using MQuant ${ }^{\mathrm{TM}}$ Peroxid-test strips (Merck), and the $\mathrm{H}_{2} \mathrm{O}_{2}$ concentration was determined by using the MyQubit Amplex ${ }^{\mathrm{TM}}$ Red Peroxide Assay (Invitrogen). Both assays were performed according to the manufacturer's recommendations.

\section{Illumina Whole-Genome Sequencing, Bioinformatic Analyses}

The genome of $M$. bovis RM16 was sequenced using HiseqIllumina technology (paired-end, $2 \times 150 \mathrm{bp}$, with an average of 3,000 X for coverage depth; Illumina, San Diego, CA) at the GATC Biotech facility (Konstanz, Germany). Bioinformatics analyses were conducted using the GenoToul Bioinformatics facility, Toulouse, France. Quality of the sequencing reads was controlled with FASTQC tool. ${ }^{1}$ De novo assembly was done using Abyss v2.1.5 (Simpson et al., 2009) and resulted in 61 contigs. The RM16 genome was annotated using the RAST pipeline (Overbeek et al., 2014). Co-linear analysis of the RM16 sequence with the genome of PG45 and HB0801 strain was performed using MUMmer 3.0 or ACT 13.0.0 software (Kurtz et al., 2004; Carver et al., 2005). The Whole Genome Shotgun project of M. bovis strain RM16 has been deposited at DDBJ/ENA/GenBank under the accession VSDF00000000. The version described in this paper is version VSDF01000000. Sequences of interest were compared for similar nucleotide sequences with BLAST-NCBI search utility. ${ }^{2}$

\section{RESULTS}

\section{Extracellular DNA Is a Limiting Nutrient for M. bovis Proliferation in Cell Culture}

Transtracheal aspirates from animals showing signs of bronchopneumonia were used to isolate $M$. bovis RM16 (Table 1). This field isolate, whose draft genome sequence was determined by illumina sequencing, was used as a low-passage strain to investigate the influence of eDNA on $M$. bovis proliferation upon co-cultivation with embryonic bovine lung (EBL) cells. RM16 and EBL cells were seeded in DMEM-based medium at a MOI of 2, and mycoplasma growth was monitored by enumerating CFUs over a period of $72 \mathrm{~h}$ (Figure 1A). Data showed that

${ }^{1}$ https://www.bioinformatics.babraham.ac.uk/projects/fastqc/

${ }^{2}$ https://blast.ncbi.nlm.nih.gov/Blast.cgi
EBL cells were required for RM16 proliferation, and DMEMbased medium alone was unable to sustain mycoplasma growth. However, EBL cells had only a limited effect on RM16 growth and maximum mycoplasma titers were about $10^{3}$-fold lower than those yielded in SP4, a medium commonly used for the propagation of mycoplasmas under axenic conditions. Remarkably, DMEM-based medium supplementation with calf thymus DNA $(10 \mu \mathrm{g} / \mathrm{ml})$ was found to dramatically enhance the proliferation of RM16 both under axenic and cell culture conditions. This growth-promoting effect was associated with important cytotoxicity for EBL cells leading to a complete cytopathic effect (CPE) after $72 \mathrm{~h}$ of co-incubation (Figure 1B). Incubation of EBL cells with calf thymus DNA alone failed to reveal any CPE ruling out any possible toxicity of the DNA solution. Finally, EBL cell density was identified as critical for RM16 cytotoxicity, since it was only observed upon $M$. bovis co-incubation with actively dividing cells (Supplementary Figure S1A).

To further demonstrate that eDNA is a limiting nutrient for the propagation of $M$. bovis in cell culture and its cytotoxicity for EBL cells, calf thymus DNA was subjected to different enzymatic digestions (Figure 1B). While RNase A and proteinase $\mathrm{K}$ had no influence, DNase I was able to abrogate the cytopathic growth of RM16 after removal of small polynucleotides generated by DNA digestion. This confirms that $M$. bovis cytotoxicity for EBL cells is induced by the growth-promoting effect of eDNA and further suggests that $M$. bovis can take the advantage of extracellular polynucleotides for its proliferation in cell culture. Nucleic acid requirements of $M$. bovis were further investigated by evaluating the CPE induced by RM16 proliferation. The DNA concentration needed to reach 50\% CPE in $72 \mathrm{~h}$ was estimated at about $5 \mu \mathrm{g} / \mathrm{ml}$ using DNA of eukaryotic (calf thymus) or prokaryotic (Escherichia coli K-12 DH10B) origin. Yeast tRNAs, alone or in combination with calf thymus DNA, had only a limited influence on the cytotoxicity of RM16 for EBL cells (Supplementary Figure S1B).

These results clearly identify eDNA as a nutritional trigger of the M. bovis cytopathic effect on cultured cells.

\section{M. bovis Cytotoxicity Is Linked to Pyruvate Metabolism}

To identify genomic regions that are critical for M. bovis cytotoxicity, a library of 3,072 individual mutants was generated by transposon mutagenesis in RM16, and non-cytopathic mutants were selected by high-throughput screening in cell culture. Transposon mutagenesis was performed by using a modified version of Tn4001 (mTn). Because $\mathrm{mTn}$ contains a gentamicin-resistance marker but no transposase gene, its random insertion in the mycoplasma genome is stable in addition to conferring antibiotic resistance. By using this screening strategy, 13 non-cytopathic mutants were selected that revealed 12 unique $\mathrm{mTn}$ insertion sites distributed within eight coding sequences (CDS) (Table 2). The two CDS found disrupted in mutants T1.77, T14.18, and T15.101 (Table 2) were consistent with our previous studies that identified apt and the sufS-sufU locus as essential for the proliferation of Mycoplasma agalactiae in cell culture (Baranowski et al., 2010; Skapski et al., 2011). These three mutants were not further 

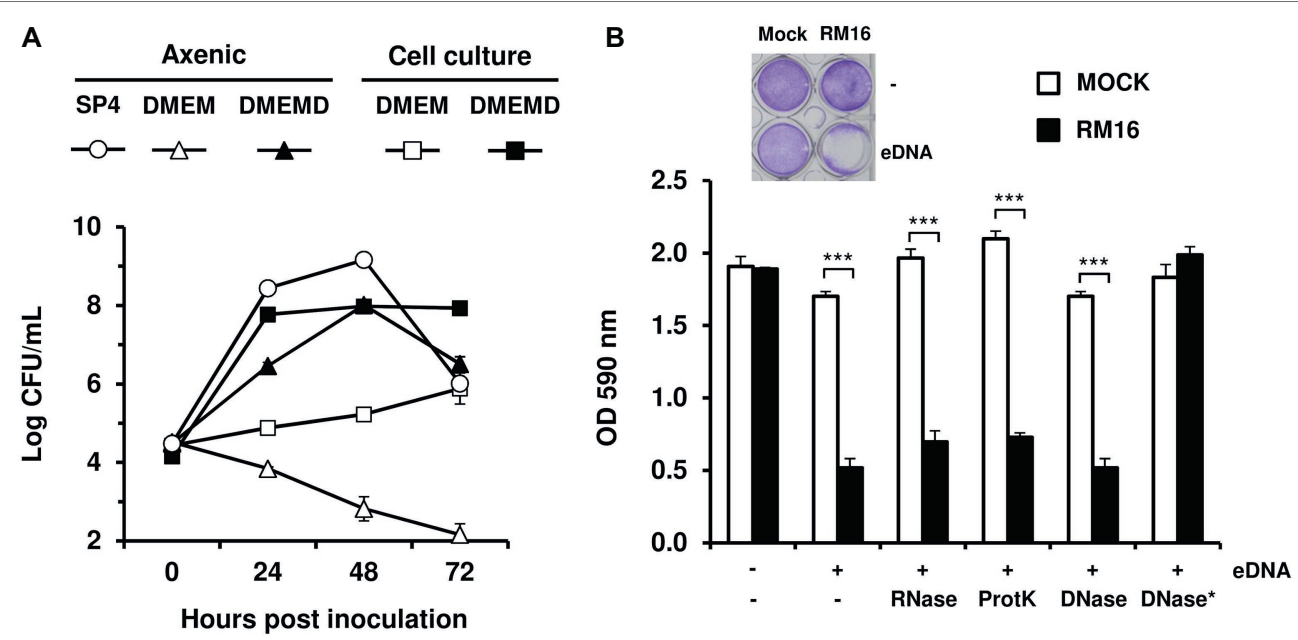

FIGURE 1 | The growth-promoting effect of eDNA on M. bovis. Comparative growth of M. bovis under axenic and cell culture conditions (A). RM16 proliferation was monitored in SP4 medium (SP4), cell culture medium (DMEM), and cell culture medium supplemented with $10 \mu \mathrm{g} / \mathrm{ml}$ calf thymus DNA (DMEMD). Mycoplasma titers (log CFU/ml) were determined by CFU titrations. The cytopathic effect induced by $M$. bovis upon co-incubation with host cells (B). EBL cells (10 ${ }^{4}$ cells) were inoculated with RM16 at an MOI of 2 (RM16) or mock-infected (Mock). After $72 \mathrm{~h}$ of co-incubation, monolayers were stained with crystal violet and survival cells were estimated by measuring the optical density at $590 \mathrm{~nm}$ (OD 590). When indicated, DMEM-based medium was supplemented with $10 \mu \mathrm{g} / \mathrm{ml}$ calf thymus DNA (eDNA). Calf thymus DNA was subjected to the following enzymatic treatments: RNase A (RNase), Proteinase K (ProtK) and DNase I (DNase) digestion (see section "Materials and Methods"). The asterisk indicates that polynucleotides were removed from DNase I digestion products (DNase*). Infected and mock-infected samples were treated identically. Data are the means of at least three independent assays. Standard deviations are indicated by error bars. $p$-values were determined by using two-sided independent sample $t$ tests and comparing OD590 values of RM16-infected samples to those of mock-infected samples $\left.{ }^{* \star *} p<0.001\right)$.

TABLE 2 | Transposon insertion sites in the chromosome of non-cytopathic M. bovis mutants.

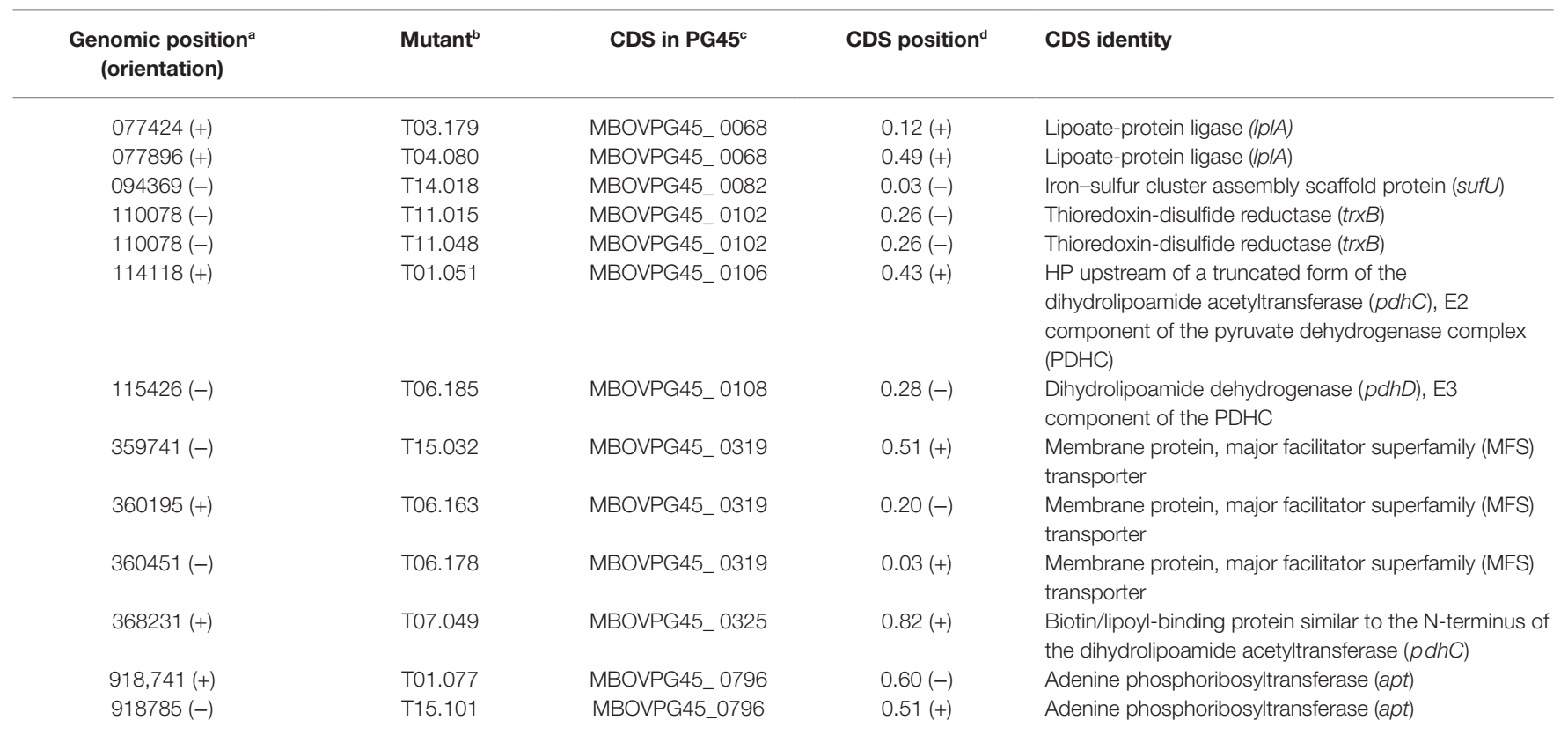

${ }^{a}$ The position of the $m T n$ insertion was defined based on the PG45 published sequence in GenBank database (CP002188.1). The orientation of the mTn is given in parenthesis using the gentamicin-resistance marker as a reference. The $\mathrm{mTn}$ in T11.15 and T11.48 was inserted at the same chromosomal position.

${ }^{b}$ Mutants were designated according to transformation and clone numbers (e.g., T03.179 designates clone 179 isolated from transformation T03).

${ }^{\circ}$ The CDS found disrupted in M. bovis are indicated by their mnemonic codification in GenBank.

${ }^{d}$ For each CDS, the relative position and orientation of the $\mathrm{mTn}$ are indicated.

characterized since their non-cytopathic phenotype was associated with a severe growth deficiency in cell culture (data not shown). The non-cytopathic mutants, whose proliferation in cell culture produced CFU titers similar to RM16 (Figure 2A), were characterized by a transposon inserted within six CDS located at three distant chromosomal regions (Figure 3). Remarkably, 


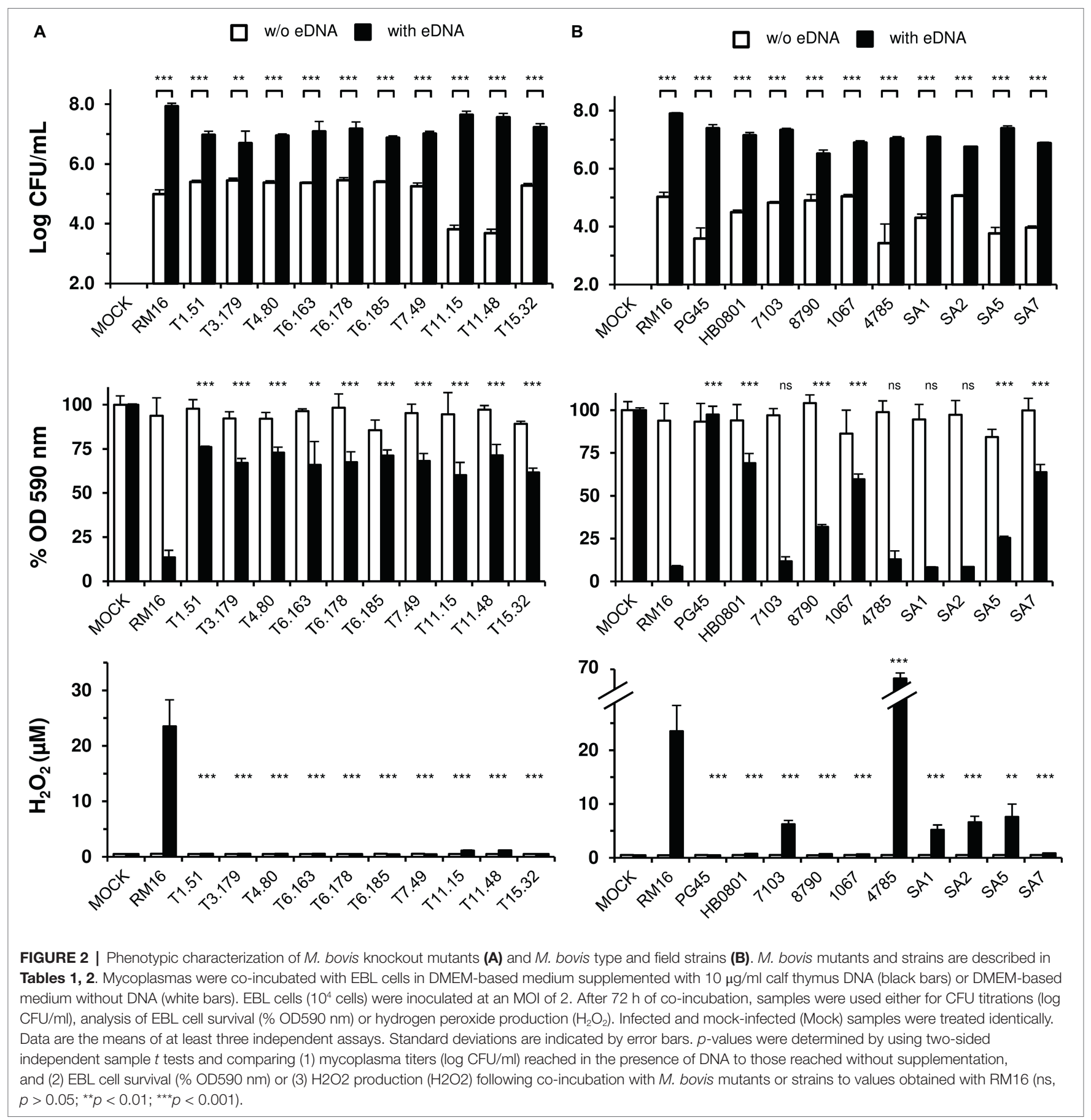

several CDS found disrupted in these distant regions were homologous to components of the pyruvate dehydrogenase (PDH) complex or were located in close proximity to this gene cluster (Figure 3 and Table 2). These included (1) a $p d h D$ homolog (mutant T6.185), (2) a CDS sharing similarity with the N-terminus of $p d h C$, which is located upstream of the lactate dehydrogenase homolog in RM16 (mutant T07.49), (3) a CDS encoding a hypothetical protein with unknown function located in front of the C-terminus of $p d h C$ (mutant T01.051), and (4) a CDS predicted to encode a lipoate protein ligase that catalyzes the transfer of lipoic acid to lipoate-dependent enzymes, such as the lipoamide dehydrogenase of the PDH complex (mutants T3.179 and T4.80). Finally, two additional regions were found repeatedly disrupted in non-cytopathic mutants. These included a thioredoxin reductase $\operatorname{TrxB}$ gene homolog (mutants T11.15 and T11.48) and a CDS predicted to encode a putative membrane protein belonging to the major facilitator superfamily (MFS), a family of permease that facilitates the movement of small solutes 

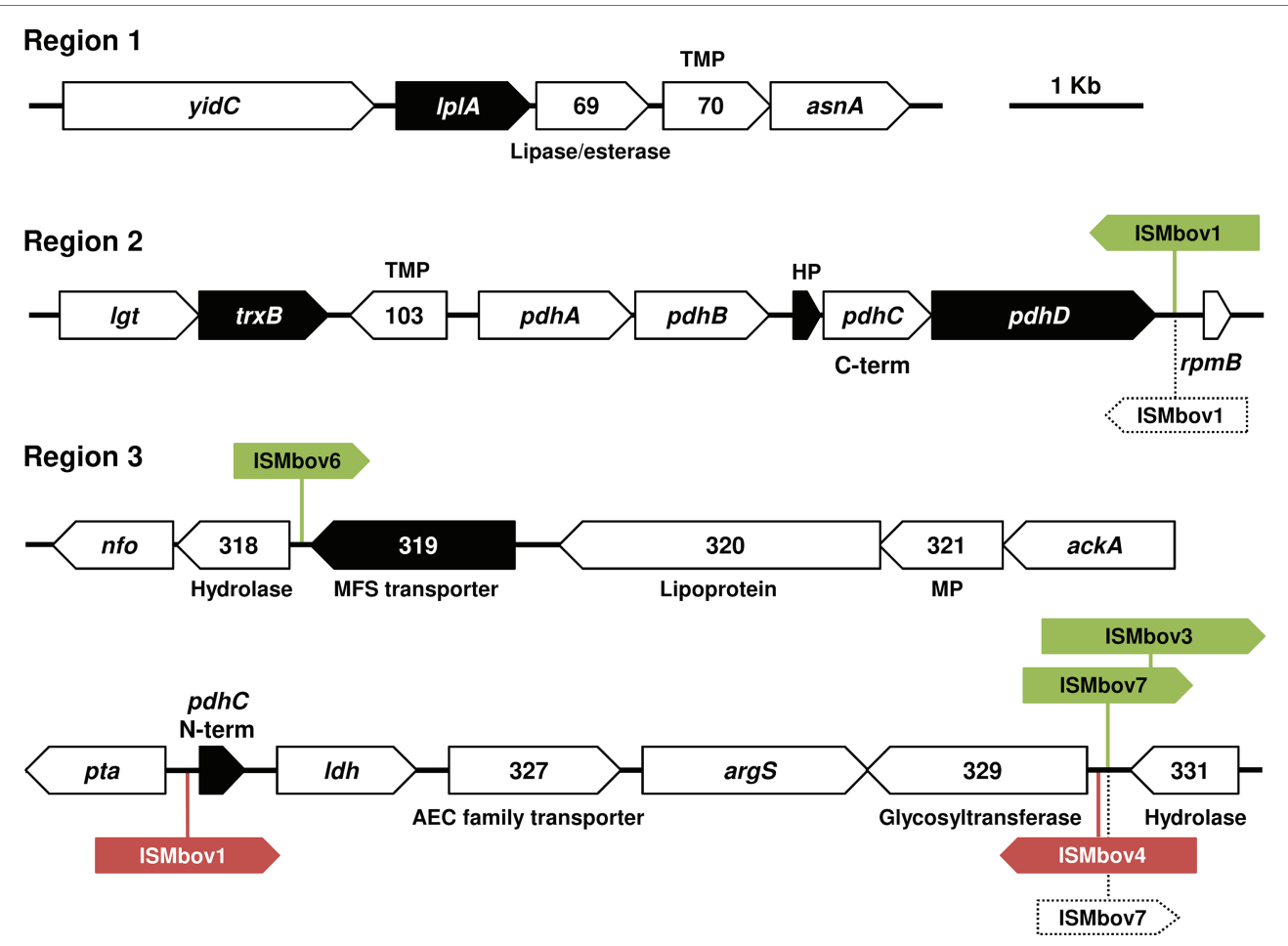

FIGURE 3 | Analysis of M. bovis loci in non-cytopathic mutants. For each locus, CDS found disrupted in non-cytopathic mutants are indicated by black arrows (Table 2) and surrounding CDS by open arrows. The CDS annotations are indicated either by the gene name or the MBOVPG45 locus tag number. Putative functions or features of CDS products are indicated when available: MP, membrane protein; HP, hypothetical proteins; Lipo, lipoproteins. Green and red arrows indicate the position and name of IS transposase in the genome of $M$. bovis strains HB0801 and PG45, respectively. The occurrence of IS-elements in the draft genome sequence of RM16 was suggested by sequence homology at contig ends. The position of these IS-elements in RM16 is are indicated by dotted boxes.

across cell membranes in response to chemiosmotic ion gradients (mutants T15.32, T6.163, and T6.178).

These data suggest that housekeeping functions linked to pyruvate metabolism may influence the cytotoxicity of M. bovis in cell culture.

\section{Hydrogen Peroxide Production by M. bovis Is Cytotoxic for Embryonic Bovine Lung Cells}

The $\mathrm{PDH}$ is a key enzymatic complex linking glycolysis to citric acid cycle. Under aerobic conditions, this complex catalyzes the conversion of pyruvate into acetyl-CoA and produces NADH. In $M$. bovis, the $\mathrm{NAD}^{+}$pool can be regenerated by an $\mathrm{H}_{2} \mathrm{O}_{2}$ producing NADH oxidase (Zhao et al., 2017). This prompted us to examine whether $M$. bovis was able to produce $\mathrm{H}_{2} \mathrm{O}_{2}$ under cell culture conditions (Figure 2A). Interestingly, robust production of $\mathrm{H}_{2} \mathrm{O}_{2}$ reaching up to $30 \mu \mathrm{M}$ was detected for RM16, whereas non-cytopathic mutants produced undetectable levels of $\mathrm{H}_{2} \mathrm{O}_{2}$. As expected, $\mathrm{H}_{2} \mathrm{O}_{2}$ production by RM16 was conditioned by the presence of calf thymus DNA (Figure 2A). Since defense mechanisms developed by mammalian cells against oxidative stress may decrease the amount of $\mathrm{H}_{2} \mathrm{O}_{2}$ produced by $M$. bovis, we reexamined the capacity of RM16 and non-cytopathic mutants to produce $\mathrm{H}_{2} \mathrm{O}_{2}$ in axenic conditions using
DMEM-based medium supplemented with eDNA (Supplementary Figure S2). The composition of the DMEM-based medium was also modified by removing the pyruvate, which is well known for having $\mathrm{H}_{2} \mathrm{O}_{2}$-scavenging properties. In these conditions, RM16 was found to produce higher levels of $\mathrm{H}_{2} \mathrm{O}_{2}$ reaching up to $75 \mu \mathrm{M}$ and two non-cytopathic mutants, namely T11.15 and T11.48, produced about $25 \mu \mathrm{M}$ of $\mathrm{H}_{2} \mathrm{O}_{2}$. Surprisingly, these two mutants were characterized by a mTn insertion in $\operatorname{tr} x B$ whose function is usually to protect bacteria from the toxic effects of $\mathrm{H}_{2} \mathrm{O}_{2}$ ( $\mathrm{Lu}$ and Holmgren, 2014). Interestingly, $\operatorname{tr} x B$ is located a few kps upstream of the PHD locus ( $p d h A, p d h B, p d h C$, and $p d h D$ ) (Figure 3). Whether the phenotype observed in T11.15 and $\mathrm{T} 11.48$ is due to $\operatorname{tr} x B$ inactivation or to a polar effect of the mTn insertion on the PHD locus remains to be elucidated.

The cytotoxicity of $\mathrm{H}_{2} \mathrm{O}_{2}$ has been extensively studied in several mycoplasma species (Blötz and Stülke, 2017). In the ruminant pathogen Mycoplasma mycoides subsp. mycoides, cytotoxicity was associated with a glycerol-3-phosphate oxidase GlpO found at the mycoplasma membrane surface suggesting that close contact to the host cell is required (Pilo et al., 2005). In RM16, the production of $\mathrm{H}_{2} \mathrm{O}_{2}$ was found independent of glycerol metabolism since cell culture medium supplementation with glycerol $(100 \mu \mathrm{M})$ failed to induce detectable production of $\mathrm{H}_{2} \mathrm{O}_{2}$ (data not shown). This result was consistent with the lack of a $g l p O$ homolog in RM16 and whole-genome sequences of $M$. bovis available in 
databases. Another particular feature of RM16 is that cytotoxicity was not dependent on close contact between bacteria and EBL cells since the amount of $\mathrm{H}_{2} \mathrm{O}_{2}$ released by $\mathrm{RM} 16$ in the cell culture medium can induce cytotoxicity. This was shown by using gentamicin-treated cell culture supernatants collected after $72 \mathrm{~h}$ of co-incubation with RM16 (Supplementary Figure S1C). Indeed, these bacteria-free supernatants were found cytotoxic for EBL cells. Catalase $(60 \mathrm{U} / \mathrm{ml})$ was shown to abolish the cytotoxicity of the supernatants discarding any possible cytotoxic effect due to the depletion of nutrients.

These results clearly identified $\mathrm{H}_{2} \mathrm{O}_{2}$ as responsible for the cytotoxicity of RM16 and further suggest that this toxic metabolic compound may be a common virulence factor in ruminant mycoplasma species, although several different metabolic pathways may be involved.

\section{Intra-species Differences in eDNA- Mediated $M$. bovis Cytotoxicity and $\mathrm{H}_{2} \mathrm{O}_{2}$ Production}

The CDS organization of the three genomic regions associated with $\mathrm{H}_{2} \mathrm{O}_{2}$ production in RM16 was found highly conserved in M. bovis strains PG45 and HB0801, and only differ by the presence of several insertion sequences (IS) elements (Figure 3). However, previous studies reported important intra-species differences in $\mathrm{H}_{2} \mathrm{O}_{2}$ production (Khan et al., 2005). This led us to further characterize the cytopathic properties of $M$. bovis using a collection of type and field strains (Table 1). As expected, eDNA was found to have a dramatic effect on their proliferation with mycoplasma titers reaching values ranging from $3.4 \times 10^{6}$ to $7.9 \times 10^{7} \mathrm{CFU} /$ $\mathrm{ml}$ after $72 \mathrm{~h}$ of co-incubation with EBL cells (Figure 2B). Interestingly, staining with crystal violet revealed important differences in the survival of EBL cells, with strains RM16, 7103, 4785, SA1, SA2, and SA5 displaying survival rates lower than 25\% when compared to mock-infected EBL cells, and strain PG45 having no cytotoxicity. Strains HB0801, 8790, 1067, and SA7 were characterized by an intermediate level of cytotoxicity with survival rates ranging from 25 to $75 \%$. These differences showed no obvious correlation with mycoplasma titers (Figure 2B). For instance, the survival rate associated with strain 8790 was $32 \%$ with a mycoplasma titer of $3.4 \times 10^{6} \mathrm{CFU} / \mathrm{ml}$, while the non-cytopathic strain PG45 reached up to $2.6 \times 10^{7} \mathrm{CFU} / \mathrm{ml}$. Important differences were also observed in the amount of $\mathrm{H}_{2} \mathrm{O}_{2}$ measured after $72 \mathrm{~h}$ of co-incubation with EBL cells (Figure 2B). Interestingly, $M$. bovis strains producing undetectable levels of $\mathrm{H}_{2} \mathrm{O}_{2}$ were found poorly cytopathic, with survival rates higher than $50 \%$. Conversely, survival rates lower than $50 \%$ were associated with the production of $5-68 \mu \mathrm{M}$ of $\mathrm{H}_{2} \mathrm{O}_{2}$. One exception was 8790 , an atypical strain of $M$. bovis isolated from caprine that displayed an intermediate level on cytotoxicity (32\%) with no production of $\mathrm{H}_{2} \mathrm{O}_{2}$. As observed for RM16, M. bovis strains tested were only found cytotoxic for actively dividing EBL cells but not confluent monolayers (Supplementary Figure S1A).

Whether mobile IS-elements may influence $M$. bovis production of $\mathrm{H}_{2} \mathrm{O}_{2}$ is unknown. However, the occurrence of these mobile elements at close proximity of several CDS found disrupted in RM16 non-cytopathic mutants provides a reasonable scenario for explaining the absence of $\mathrm{H}_{2} \mathrm{O}_{2}$ production by PG45 and HB0801. The recent release of $M$. bovis draft genome sequences in databases led us to further examine the influence of IS-elements on $\mathrm{H}_{2} \mathrm{O}_{2}$ production. The alignment of PG45 with the draft genome sequence of 1067 revealed several contigs ending at positions corresponding to IS-elements in PG45 suggesting a conserved organization at genomic regions associated with $\mathrm{H}_{2} \mathrm{O}_{2}$ production in these two strains that were found unable to produce detectable levels of this metabolic compound. In contrast, no IS-element was identified in the atypical strain 8790 suggesting that additional genomic regions may modulate $\mathrm{H}_{2} \mathrm{O}_{2}$ production in this distant phylogenic species.

The cytotoxicity of $M$. bovis for EBL cells raised questions regarding the role of eDNA and $\mathrm{H}_{2} \mathrm{O}_{2}$ production on its virulence upon replication in the natural host. To address this issue, we have compared the cytotoxicity of the virulent strain HB0801 with its attenuated derivative P150 which was selected by 150 serial passages under axenic conditions (Zhang et al., 2014). Upon co-cultivation with EBL cells, HB0801 and P150 displayed intermediate levels of cytotoxicity with survival rates of about 50 and 75\%, respectively (Figure 4A). As expected by our previous results, neither $\mathrm{HB} 0801$ nor $\mathrm{P} 150$ was able to produce detectable levels of $\mathrm{H}_{2} \mathrm{O}_{2}$ in cell culture, despite medium supplementation with calf thymus DNA. Since HB0801 and P150 were previously found to produce $\mathrm{H}_{2} \mathrm{O}_{2}$ (Rasheed et al., 2017), we re-examined their capacity to produce of $\mathrm{H}_{2} \mathrm{O}_{2}$ in axenic conditions using DMEM-based medium supplemented with eDNA (Figure 4B). In these conditions, HB0801 was found to produce detectable levels of $\mathrm{H}_{2} \mathrm{O}_{2}$ (estimated at 5-15 $\mu \mathrm{M})$, whereas $\mathrm{H}_{2} \mathrm{O}_{2}$ production by $\mathrm{P} 150$ remained undetectable despite similar mycoplasma titers (Figure 4B). These results confirm that long-term serial propagation of HB0801 in axenic conditions led to the selection of variants with decreased production of $\mathrm{H}_{2} \mathrm{O}_{2}$ (Rasheed et al., 2017). The alignment of P150 with the genome of HB0801 identified a single nucleotide deletion in the CDS located upstream of $l p l A$ (Figure 3), which was found disrupted in RM16 non-cytopathic mutants T3.179 and T4.080 (Table 2). This deletion occurred in poly-A tract located in the central part of the CDS (genomic positions 76308-76315 in $\mathrm{HB} 0801$ and 76306-76312 in P150) leading to a truncation of its C-terminal region. Whether these changes are contributing to the attenuated phenotype of P150 is unknown, but they provide valuable information for the study of virulence factors in this pathogenic mycoplasma species.

Altogether, these data identify $\mathrm{H}_{2} \mathrm{O}_{2}$ production as contributing to the cytotoxicity of $M$. bovis under cell culture conditions and further suggest that additional mechanisms may also contribute to its cytopathogenicity.

\section{DISCUSSION}

Competition for nutrients is a fundamental aspect of hostmicrobe interactions. Despite important nutritional requirements, only limited information is available regarding the mechanisms 


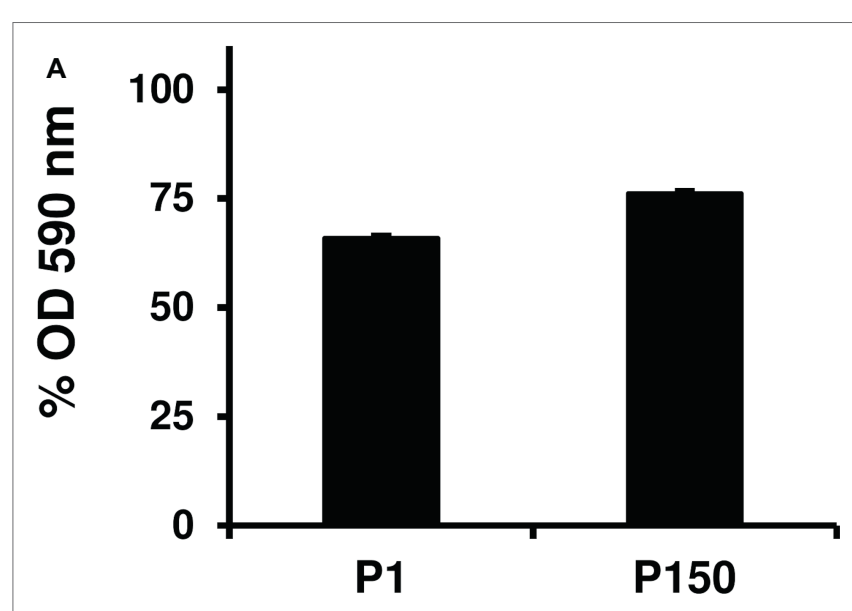

B
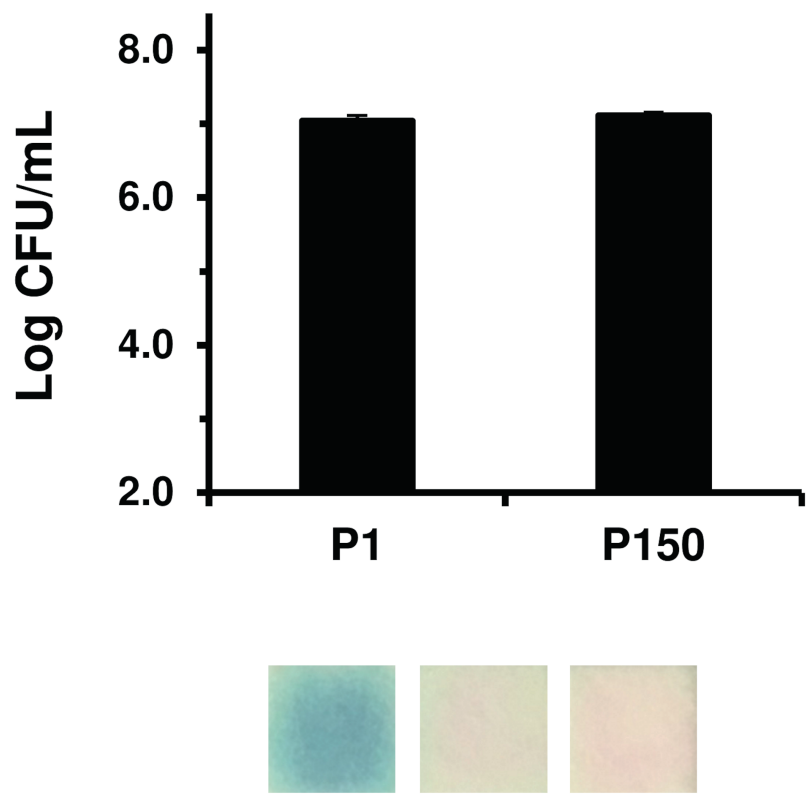

P1

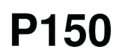

$-$

FIGURE 4 | Phenotypic characterization of $M$. bovis vaccine strain P150. EBL cell survival (\% OD590 nm) after $72 \mathrm{~h}$ of co-incubation with HB0801 (P1) and P150 (P150) in DMEM-based medium supplemented with $10 \mu \mathrm{g} / \mathrm{ml}$ calf thymus DNA (A). Mycoplasma titers (log CFU/ml) reached by P1 and P150 after 48 h incubation in axenic DMEM-based medium without pyruvate and supplemented with $10 \mu \mathrm{g} / \mathrm{ml}$ calf thymus DNA and $\mathrm{H}_{2} \mathrm{O}_{2}$ production as determined by using MQuantTM Peroxid-test strips (B). Data are the means of at least three independent assays. Standard deviations are indicated by error bars.

that mycoplasmas have evolved to meet these requirements and the contribution of these mechanisms to virulence. Here, we showed that eDNA is a limiting nutrient for $M$. bovis proliferation upon co-cultivation with bovine lung cells. Indeed, medium supplementation with eDNA was found to dramatically enhance mycoplasma growth under cell culture conditions leading to cytopathic manifestations due to $\mathrm{H}_{2} \mathrm{O}_{2}$ production.

\section{The Pathometabolism of Minimal Bacteria}

Studies with the ruminant pathogen Mycoplasma mycoides subsp. mycoides provided early evidence that carbon metabolism is intimately linked to pathogenicity in the mollicutes (Pilo et al., 2007; Blötz and Stülke, 2017). The genetic and biochemical characterization of glycerol uptake in two distinct phylogenetic lineages showing differences in their pathogenicity identified glycerol metabolism and $\mathrm{H}_{2} \mathrm{O}_{2}$ production as a potential virulence factor in this species (Vilei and Frey, 2001). In cell culture, the $\mathrm{H}_{2} \mathrm{O}_{2}$ producing glycerol-3-phosphate oxidase GlpO was shown to be responsible for the massive cytopathic effect induced by pathogenic strains of $M$. mycoides subsp. mycoides upon addition of glycerol in the culture medium (Pilo et al., 2005; Bischof et al., 2008). Remarkably, no GlpO homolog has been identified in $M$. bovis genome sequences available in databases, suggesting that this species has evolved glycerolindependent mechanisms of virulence (Bürki et al., 2015).

Recently, the hydrogen sulfide producing cysteine desulfurase/ desulfhydrase HapE of M. pneumoniae was found to promote erythrocyte lysis and to alter the cytokine profile and growth of bronchial epithelial cells (Großhennig et al., 2016; Li et al., 2019b). Previously annotated as a cysteine desulfurase NifS/ SufS, HapE is highly conserved across Mollicutes together with the iron-sulfur cluster assembly scaffold protein (SufU). Whether other pathogenic species are producing hydrogen sulfide is unknown, but the sufS-sufU locus in the ruminant pathogen $M$. agalactiae was found essential for survival in cell culture and colonization of the animal host (Baranowski et al., 2010, 2014; Skapski et al., 2011). The growth-deficient phenotype of mutant 14.018 (Table 2) confirmed the role of the sufS-sufU locus in $M$. bovis proliferation in cell culture. The close genetic proximity between $M$. agalactiae and $M$. bovis further suggests a possible role in host colonization.

Transposon mutagenesis in $M$. bovis suggests that glycerolindependent mechanisms of $\mathrm{H}_{2} \mathrm{O}_{2}$ production and cytotoxicity may be linked to pyruvate metabolism. Further studies are needed to confirm these results, but the release of cytotoxic metabolic compounds is emerging as pivotal in the pathometabolism of these minimal organisms. The release of $\mathrm{H}_{2} \mathrm{O}_{2}$ by $\mathrm{RM} 16$ in our experimental conditions was estimated at about $30 \mu \mathrm{M}$, a value 5-fold lower than those reported for the highly pathogenic M. mycoides subsp. mycoides pathogenic strain Afadé (Vilei and Frey, 2001; Pilo et al., 2005). Despite different experimental conditions, this result was consistent with the lower cytotoxicity of RM16 that was only observed upon co-incubation with actively dividing cells but not confluent monolayers. Since glycerol is metabolized into pyruvate under aerobic conditions, M. mycoides subsp. mycoides may take advantage of these two pathways to produce high levels of $\mathrm{H}_{2} \mathrm{O}_{2}$. While the $\mathrm{NADH}$ oxidase (Nox) is likely to be the main enzyme responsible for $\mathrm{H}_{2} \mathrm{O}_{2}$ production during pyruvate metabolism, both Nox and GlpO may be involved in glycerol metabolism. The M. mycoides subsp. mycoides GlpO (Pilo et al., 2005) and the M. bovis Nox (Zhao et al., 2017) enzymes have both been reported to be associated to the mycoplasma membrane and in close contact with the host cells. 
In our hands, close contact between $M$. bovis and the host cells is not required for cytotoxicity, at least for actively dividing cells. Recent evidences support the cytoplasmic localization of GlpO in members of the Mycoplasma mycoides cluster (Schumacher et al., 2019), thus raising questions regarding the mechanisms facilitating the release of $\mathrm{H}_{2} \mathrm{O}_{2}$ from mycoplasma cells. Recent studies on different organisms have highlighted the role of water-permeable aquaporins in the transmembrane diffusion of $\mathrm{H}_{2} \mathrm{O}_{2}$ across biological membranes (Bienert and Chaumont, 2014). Interestingly, transposon mutagenesis identified a putative membrane protein of the major facilitator superfamily (MFS) among candidate genes involved $\mathrm{H}_{2} \mathrm{O}_{2}$ production in $M$. bovis. Whether members of the MFS in mycoplasmas may facilitate the export of $\mathrm{H}_{2} \mathrm{O}_{2}$ remains to be demonstrated, but the occurrence of such transporter would be consistent with the absence of $\mathrm{H}_{2} \mathrm{O}_{2}$-degrading enzymes in these organisms.

The contribution $\mathrm{H}_{2} \mathrm{O}_{2}$ production to the virulence of pathogenic mycoplasma species is still controversial (Szczepanek et al., 2014; Schumacher et al., 2019), and the role of eDNA and $\mathrm{H}_{2} \mathrm{O}_{2}$ production in $M$. bovis pathogenesis needs to be confirmed in vivo. However, our study provides insight into the mechanism responsible for $M$. bovis host cell cytotoxicity, clearly demonstrating that $\mathrm{H}_{2} \mathrm{O}_{2}$ production is independent from glycerol metabolism but required eDNA. The importance of eDNA in the biology of $M$. bovis is consistent with functional genomic studies with several ruminant mycoplasma species that identified nucleotide metabolism as essential for their survival in cell culture, while dispensable for axenic growth (Baranowski et al., 2010; Skapski et al., 2011; Josi et al., 2019). Finally, nucleases and polynucleotide binding proteins are common component of the mycoplasma surface, besides their role in the acquisition of nutrients these surface proteins are also emerging as potential virulence factors (Minion and Goguen, 1986; Minion et al., 1993; Bendjennat et al., 1999; Jarvill-Taylor et al., 1999; Schmidt et al., 2007; Li et al., 2010, 2018, 2019a; Somarajan et al., 2010; Szczepanek et al., 2010; Browning et al., 2011; Cacciotto et al., 2013, 2019; Masukagami et al., 2013; Sharma et al., 2015; Xu et al., 2015; Yacoub and Mardassi, 2016; Zhang et al., 2016; Gondaira et al., 2017; Yamamoto et al., 2017; Mitiku et al., 2018; Qin et al., 2019).

\section{M. bovis Is Frequently Exposed to eDNA in vivo}

During its replication in the natural host, $M$. bovis can be frequently exposed to eDNA (Figure 5). This ubiquitous material of terrestrial and aquatic environments can also be isolated from many biological fluids (Vorkapic et al., 2016; Aucamp et al., 2018; Nagler et al., 2018). In normal and diseased tissues, necrosis and apoptosis are the main sources of eDNA, together with autophagy and pyroptosis (Aucamp et al., 2018). Besides these cellular breakdown mechanisms, eDNA can be actively released from living cells either encapsulated in vesicles or in the form of DNA/RNA lipoprotein complexes, termed as virtosomes (Aucamp et al., 2018). Invading pathogens are also contributing to the release

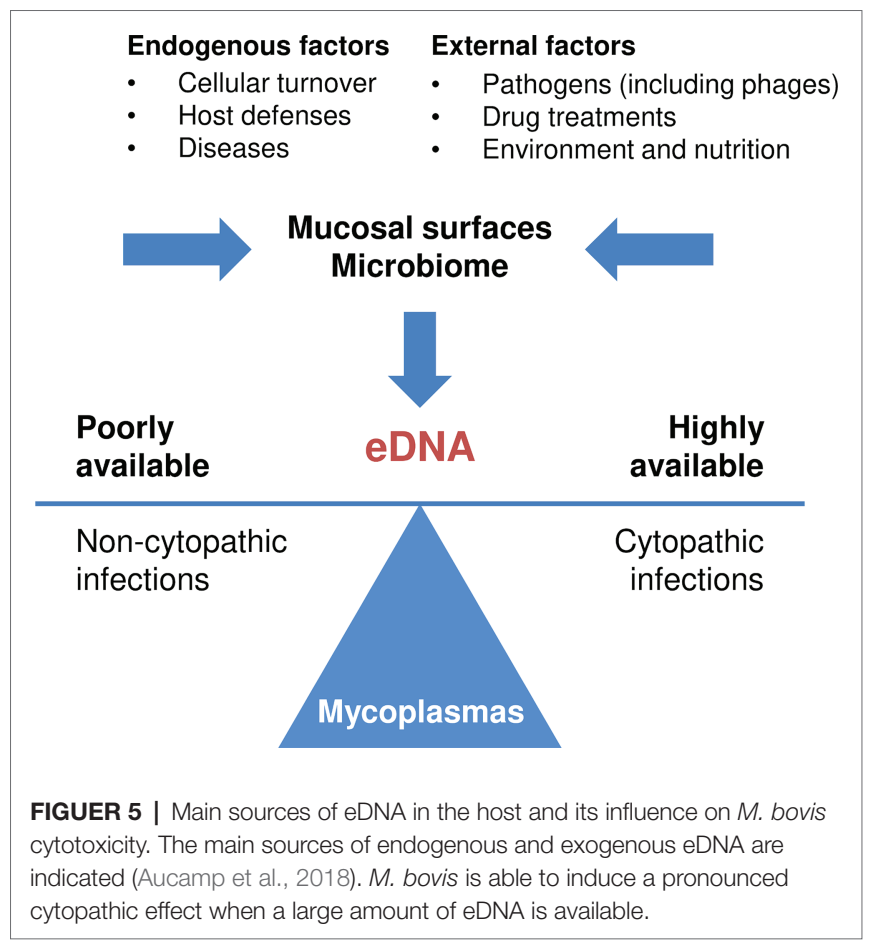

of cellular DNA, either directly by damaging the integrity of the infected tissues or indirectly as the outcome of the host immune responses (see below). Ultimately, a significant part of eDNA in the host is also provided by microbial communities (Vorkapic et al., 2016; Nagler et al., 2018).

Mycoplasmas have a predilection for mucosal surfaces of the respiratory and genital tracts. The rapid turnover of epithelial cells may thus provide an important source of eDNA to these organisms. M. bovis is a re-emerging cause of pneumonia and mastitis in cattle. This economically important species is associated with the bovine respiratory disease complex, a multifactorial disease resulting from complex interactions between environmental, management and host factors, as well as from viral and bacterial co-infections. Viral co-infections have been shown to enhance pulmonary lesions caused by $M$. bovis (Prysliak et al., 2011). Since viral infections and host defenses are responsible for important damages of host tissues, it would be interesting to evaluate the contribution of DNA release on the development of $M$. bovis pneumonia. Another source of eDNA with particular importance for the control of invading pathogens is the activation and release of neutrophil extracellular traps (NET), a complex network of extracellular fibers, primarily composed of DNA and antimicrobial proteins. Recent studies suggested that the DNAse expressed at the surface of M. bovis is a key factor for escaping NETs (Zhang et al., 2016; Gondaira et al., 2017; Mitiku et al., 2018). Our data further suggest that $M$. bovis can take advantage of NETs for its proliferation in the animal host, as previously suggested for the swine pathogen Mycoplasma hyopneumoniae that was found able to degrade macrophage extracellular traps and incorporate those host nucleotides into its own DNA (Henthorn et al., 2018). The 
eDNA is also an important structural component of the biofilm matrix raising interesting questions about the interplay between mycoplasmas and microbial communities. Finally, it is noteworthy that bacteriophages and antimicrobial drugs are contributing to the release of massive amounts of prokaryotic DNA.

This study confirms the multifaceted role of eDNA in microbial communities and further identifies this ubiquitous material as a nutritional trigger of $M$. bovis cytotoxicity. $M$. bovis may thus take advantage of the multiple sources of eDNA in vivo to modulate its interaction with host cells (Figure 5), a way to overcome its limited coding capacity.

\section{DATA AVAILABILITY STATEMENT}

The datasets generated for this study can be found in the GenBank database under the accession number VSDF00000000 (BioProject: PRJNA556134; BioSample: SAMN12340981).

\section{AUTHOR CONTRIBUTIONS}

AG, CC, and EB contributed conception and design of the study. XZ, LG, and $\mathrm{M}-\mathrm{CH}$ were involved in cell culture studies. $\mathrm{AB}$ and $\mathrm{ES}$ were involved in the construction of the mutant library. ED-F and LN performed sequence analysis. XZ, SA, and RM were involved in mycoplasma cultures. EB wrote the first draft of the manuscript. XZ and ED-F wrote sections of

\section{REFERENCES}

Aucamp, J., Bronkhorst, A. J., Badenhorst, C. P. S., and Pretorius, P. J. (2018). The diverse origins of circulating cell-free DNA in the human body: a critical re-evaluation of the literature. Biol. Rev. Camb. Philos. Soc. 93, 1649-1683. doi: 10.1111/brv.12413

Baranowski, E., Bergonier, D., Sagné, E., Hygonenq, M.-C., Ronsin, P., Berthelot, X., et al. (2014). Experimental infections with Mycoplasma agalactiae identify key factors involved in host-colonization. PLoS One 9:e93970. doi: 10.1371/ journal.pone.0093970

Baranowski, E., Guiral, S., Sagné, E., Skapski, A., and Citti, C. (2010). Critical role of dispensable genes in Mycoplasma agalactiae interaction with mammalian cells. Infect. Immun. 78, 1542-1551. doi: 10.1128/IAI.01195-09

Bendjennat, M., Blanchard, A., Loutfi, M., Montagnier, L., and Bahraoui, E. (1999). Role of Mycoplasma penetrans endonuclease P40 as a potential pathogenic determinant. Infect. Immun. 67, 4456-4462.

Bienert, G. P., and Chaumont, F. (2014). Aquaporin-facilitated transmembrane diffusion of hydrogen peroxide. Biochim. Biophys. Acta 1840, 1596-1604. doi: 10.1016/j.bbagen.2013.09.017

Bischof, D. F., Janis, C., Vilei, E. M., Bertoni, G., and Frey, J. (2008). Cytotoxicity of Mycoplasma mycoides subsp. mycoides small colony type to bovine epithelial cells. Infect. Immun. 76, 263-269. doi: 10.1128/IAI.00938-07

Blokesch, M. (2017). In and out-contribution of natural transformation to the shuffling of large genomic regions. Curr. Opin. Microbiol. 38, 22-29. doi: 10.1016/j.mib.2017.04.001

Blötz, C., and Stülke, J. (2017). Glycerol metabolism and its implication in virulence in mycoplasma. FEMS Microbiol. Rev. 41, 640-652. doi: 10.1093/ femsre/fux033

Browning, G. F., Marenda, M. S., Noormohammadi, A. H., and Markham, P. F. (2011). The central role of lipoproteins in the pathogenesis of mycoplasmoses. Vet. Microbiol. 153, 44-50. doi: 10.1016/j.vetmic.2011.05.031 the manuscript. All authors contributed to manuscript revision, read, and approved the submitted version.

\section{FUNDING}

This work was supported by financial supports from INRA and ENVT, and grants from the National Nature Science Foundation of China (NSFC) (31772745), Wuhan International Science and Technology Cooperation Program (2017030209020258), Special Fund for Chinese Agricultural Research System (Beef/yaks) (CARS-37), the Special Fund for National Distinguished Scholars in Agricultural Research and Technical Innovative Team and the Fundamental Research Funds for the Central Universities (2013QC001).

\section{ACKNOWLEDGMENTS}

We thank R. Herrmann for providing plasmid pMT85 and M. Heller for EBL cells.

\section{SUPPLEMENTARY MATERIAL}

The Supplementary Material for this article can be found online at: https://www.frontiersin.org/articles/10.3389/fmicb.2019.02753/ full\#supplementary-material

Bürki, S., Frey, J., and Pilo, P. (2015). Virulence, persistence and dissemination of Mycoplasma bovis. Vet. Microbiol. 179, 15-22. doi: 10.1016/j.vetmic.2015.02.024

Cacciotto, C., Addis, M. F., Coradduzza, E., Carcangiu, L., Nuvoli, A. M., Tore, G., et al. (2013). Mycoplasma agalactiae MAG_5040 is a Mg2+-dependent, sugar-nonspecific SNase recognised by the host humoral response during natural infection. PLoS One 8:e57775. doi: 10.1371/journal.pone.0057775

Cacciotto, C., Dessi, D., Cubeddu, T., Cocco, A. R., Pisano, A., Tore, G., et al. (2019). MHO_0730 is a surface-exposed calcium-dependent nuclease of Mycoplasma hominis promoting neutrophils extracellular traps formation and escape. J. Infect. Dis. 220, 1999-2008. doi: 10.1093/infdis/jiz406

Carver, T. J., Rutherford, K. M., Berriman, M., Rajandream, M.-A., Barrell, B. G., and Parkhill, J. (2005). ACT: the Artemis comparison tool. Bioinformatics 21, 3422-3423. doi: 10.1093/bioinformatics/bti553

Citti, C., and Blanchard, A. (2013). Mycoplasmas and their host: emerging and re-emerging minimal pathogens. Trends Microbiol. 21, 196-203. doi: 10.1016/j.tim.2013.01.003

Citti, C., Dordet-Frisoni, E., Nouvel, L. X., Kuo, C. H., and Baranowski, E. (2018). Horizontal gene transfers in mycoplasmas (Mollicutes). Curr. Issues Mol. Biol. 29, 3-22. doi: 10.21775/cimb.029.003

Citti, C., Nouvel, L.-X., and Baranowski, E. (2010). Phase and antigenic variation in mycoplasmas. Future Microbiol. 5, 1073-1085. doi: 10.2217/fmb.10.71

Das, T., Sehar, S., and Manefield, M. (2013). The roles of extracellular DNA in the structural integrity of extracellular polymeric substance and bacterial biofilm development. Environ. Microbiol. Rep. 5, 778-786. doi: 10.1111/1758-2229.12085

Gallucci, S., and Maffei, M. E. (2017). DNA sensing across the tree of life. Trends Immunol. 38, 719-732. doi: 10.1016/j.it.2017.07.012

Gautier-Bouchardon, A. V. (2018). Antimicrobial resistance in Mycoplasma spp. Microbiol. Spectr. 6:ARBA-0030-2018. doi: 10.1128/microbiolspec.ARBA-0030-2018

Gondaira, S., Higuchi, H., Nishi, K., Iwano, H., and Nagahata, H. (2017). Mycoplasma bovis escapes bovine neutrophil extracellular traps. Vet. Microbiol. 199, 68-73. doi: 10.1016/j.vetmic.2016.12.022 
Großhennig, S., Ischebeck, T., Gibhardt, J., Busse, J., Feussner, I., and Stülke, J. (2016). Hydrogen sulfide is a novel potential virulence factor of Mycoplasma pneumoniae: characterization of the unusual cysteine desulfurase/desulfhydrase HapE. Mol. Microbiol. 100, 42-54. doi: 10.1111/mmi.13300

Hegde, S., Hegde, S. M., Rosengarten, R., and Chopra-Dewasthaly, R. (2016). Mycoplasma agalactiae induces cytopathic effects in infected cells cultured in vitro. PLoS One 11:e0163603. doi: 10.1371/journal.pone.0163603

Henthorn, C. R., Chris Minion, F., and Sahin, O. (2018). Utilization of macrophage extracellular trap nucleotides by Mycoplasma hyopneumoniae. Microbiology 164, 1394-1404. doi: 10.1099/mic.0.000717

Ibáñez de Aldecoa, A. L., Zafra, O., and González-Pastor, J. E. (2017). Mechanisms and regulation of extracellular DNA release and its biological roles in microbial communities. Front. Microbiol. 8:1390. doi: 10.3389/ fmicb.2017.01390

Jarvill-Taylor, K. J., VanDyk, C., and Minion, F. C. (1999). Cloning of mnuA, a membrane nuclease gene of Mycoplasma pulmonis, and analysis of its expression in Escherichia coli. J. Bacteriol. 181, 1853-1860

Josi, C., Bürki, S., Stojilikovic, A., Wellnitz, O., Stoffel, M. H., and Pilo, P. (2018). Bovine epithelial in vitro infection models for Mycoplasma bovis. Front. Cell. Infect. Microbiol. 8:329. doi: 10.3389/fcimb.2018.00329

Josi, C., Bürki, S., Vidal, S., Dordet-Frisoni, E., Citti, C., Falquet, L., et al. (2019). Large-scale analysis of the Mycoplasma bovis genome identified nonessential, adhesion- and virulence-related genes. Front. Microbiol. 10:2085. doi: 10.3389/fmicb.2019.02085

Kannan, T. R., and Baseman, J. B. (2006). ADP-ribosylating and vacuolating cytotoxin of Mycoplasma pneumoniae represents unique virulence determinant among bacterial pathogens. Proc. Natl. Acad. Sci. USA 103, 6724-6729. doi: 10.1073/pnas.0510644103

Karlyshev, A. V., Pallen, M. J., and Wren, B. W. (2000). Single-primer PCR procedure for rapid identification of transposon insertion sites. BioTechniques 28, 1078, 1080, 1082. doi: 10.2144/00286bm05

Khan, L. A., Miles, R. J., and Nicholas, R. A. J. (2005). Hydrogen peroxide production by Mycoplasma bovis and Mycoplasma agalactiae and effect of in vitro passage on a Mycoplasma bovis strain producing high levels of $\mathrm{H}_{2} \mathrm{O}_{2}$. Vet. Res. Commun. 29, 181-188. doi: 10.1023/B:VERC.0000047506.04096.06

Kirby, T. (2018). Mycoplasma genitalium: a potential new superbug. Lancet Infect. Dis. 18, 951-952. doi: 10.1016/S1473-3099(18)30506-1

Kurtz, S., Phillippy, A., Delcher, A. L., Smoot, M., Shumway, M., Antonescu, C., et al. (2004). Versatile and open software for comparing large genomes. Genome Biol. 5:R12. doi: 10.1186/gb-2004-5-2-r12

Le Grand, D., Calavas, D., Brank, M., Citti, C., Rosengarten, R., Bézille, P., et al. (2002). Serological prevalence of Mycoplasma bovis infection in suckling beef cattle in France. Vet. Rec. 150, 268-273. doi: 10.1136/vr.150.9.268

Li, L., Krishnan, M., Baseman, J. B., and Kannan, T. R. (2010). Molecular cloning, expression, and characterization of a Ca2+-dependent, membraneassociated nuclease of Mycoplasma genitalium. J. Bacteriol. 192, 4876-4884. doi: $10.1128 / \mathrm{JB} .00401-10$

Li, P., Xu, J., Rao, H.-M., Li, X., Zhang, Y.-K., Jiang, F., et al. (2018). Mechanism of apoptosis induction by mycoplasmal nuclease MGA_0676 in chicken embryo fibroblasts. Front. Cell. Infect. Microbiol. 8:105. doi: 10.3389/fcimb.2018.00105

Li, S., Xue, G., Zhao, H., Feng, Y., Yan, C., Cui, J., et al. (2019b). The Mycoplasma pneumoniae HapE alters the cytokine profile and growth of human bronchial epithelial cells. Biosci. Rep. 39:BSR20182201. doi: 10.1042/BSR20182201

Li, P., Zhang, Y., Li, X., Zhou, W., Li, X., Jiang, F., et al. (2019a). Mycoplasma hyopneumoniae Mhp597 is a cytotoxicity, inflammation and immunosuppression associated nuclease. Vet. Microbiol. 235, 53-62. doi: 10.1016/j.vetmic.2019.05.011

Lu, J., and Holmgren, A. (2014). The thioredoxin antioxidant system. Free Radic. Biol. Med. 66, 75-87. doi: 10.1016/j.freeradbiomed.2013.07.036

Lysnyansky, I., and Ayling, R. D. (2016). Mycoplasma bovis: mechanisms of resistance and trends in antimicrobial susceptibility. Front. Microbiol. 7:595. doi: $10.3389 /$ fmicb.2016.00595

Manso-Silván, L., Dupuy, V., Lysnyansky, I., Ozdemir, U., and Thiaucourt, F. (2012). Phylogeny and molecular typing of Mycoplasma agalactiae and Mycoplasma bovis by multilocus sequencing. Vet. Microbiol. 161, 104-112. doi: 10.1016/j.vetmic.2012.07.015

Marenda, M. S., Sagné, E., Poumarat, F., and Citti, C. (2005). Suppression subtractive hybridization as a basis to assess Mycoplasma agalactiae and Mycoplasma bovis genomic diversity and species-specific sequences. Microbiology 151, 475-489. doi: 10.1099/mic.0.27590-0
Masukagami, Y., De Souza, D. P., Dayalan, S., Bowen, C., O'Callaghan, S., Kouremenos, K., et al. (2017). Comparative metabolomics of Mycoplasma bovis and Mycoplasma gallisepticum reveals fundamental differences in active metabolic pathways and suggests novel gene annotations. mSystems 2:e00055-17. doi: $10.1128 /$ mSystems.00055-17

Masukagami, Y., Tivendale, K. A., Mardani, K., Ben-Barak, I., Markham, P. F., and Browning, G. F. (2013). The Mycoplasma gallisepticum virulence factor lipoprotein MslA is a novel polynucleotide binding protein. Infect. Immun. 81, 3220-3226. doi: 10.1128/IAI.00365-13

Mell, J. C., and Redfield, R. J. (2014). Natural competence and the evolution of DNA uptake specificity. J. Bacteriol. 196, 1471-1483. doi: 10.1128/JB.01293-13

Minion, F. C., and Goguen, J. D. (1986). Identification and preliminary characterization of external membrane-bound nuclease activities in Mycoplasma pulmonis. Infect. Immun. 51, 352-354.

Minion, F. C., Jarvill-Taylor, K. J., Billings, D. E., and Tigges, E. (1993). Membrane-associated nuclease activities in mycoplasmas. J. Bacteriol. 175, 7842-7847. doi: $10.1128 /$ jb.175.24.7842-7847.1993

Mitiku, F., Hartley, C. A., Sansom, F. M., Coombe, J. E., Mansell, P. D., Beggs, D. S., et al. (2018). The major membrane nuclease MnuA degrades neutrophil extracellular traps induced by Mycoplasma bovis. Vet. Microbiol. 218, 13-19. doi: $10.1016 /$ j.vetmic.2018.03.002

Nagler, M., Insam, H., Pietramellara, G., and Ascher-Jenull, J. (2018). Extracellular DNA in natural environments: features relevance and applications. Appl. Microbiol. Biotechnol. 102, 6343-6356. doi: 10.1007/s00253-018-9120-4.

Nicholas, R., and Ayling, R. (2016). Mycoplasma in cattle. Vet. Rec. 178, 478-479. doi: 10.1136/vr.i2521

Okshevsky, M., and Meyer, R. L. (2015). The role of extracellular DNA in the establishment, maintenance and perpetuation of bacterial biofilms. Crit. Rev. Microbiol. 41, 341-352. doi: 10.3109/1040841X.2013.841639

Overbeek, R., Olson, R., Pusch, G. D., Olsen, G. J., Davis, J. J., Disz, T., et al. (2014). The SEED and the rapid annotation of microbial genomes using subsystems technology (RAST). Nucleic Acids Res. 42, D206-D214. doi: 10.1093/nar/gkt1226

Pereyre, S., Sirand-Pugnet, P., Beven, L., Charron, A., Renaudin, H., Barré, A., et al. (2009). Life on arginine for Mycoplasma hominis: clues from its minimal genome and comparison with other human urogenital mycoplasmas. PLoS Genet. 5:e1000677. doi: 10.1371/journal.pgen.1000677

Perez-Casal, J., Prysliak, T., Maina, T., Suleman, M., and Jimbo, S. (2017). Status of the development of a vaccine against Mycoplasma bovis. Vaccine 35, 2902-2907. doi: 10.1016/j.vaccine.2017.03.095

Pilo, P., Frey, J., and Vilei, E. M. (2007). Molecular mechanisms of pathogenicity of Mycoplasma mycoides subsp. mycoides SC. Vet. J. 174, 513-521. doi: 10.1016/j.tvjl.2006.10.016

Pilo, P., Vilei, E. M., Peterhans, E., Bonvin-Klotz, L., Stoffel, M. H., Dobbelaere, D., et al. (2005). A metabolic enzyme as a primary virulence factor of Mycoplasma mycoides subsp. mycoides small colony. J. Bacteriol. 187, 6824-6831. doi: 10.1128/JB.187.19.6824-6831.2005

Prysliak, T., van der Merwe, J., Lawman, Z., Wilson, D., Townsend, H., van Drunen Littel-van den Hurk, S., et al. (2011). Respiratory disease caused by Mycoplasma bovis is enhanced by exposure to bovine herpes virus 1 (BHV-1) but not to bovine viral diarrhea virus (BVDV) type 2. Can. Vet. J. 52, 1195-1202.

Qi, J., Guo, A., Cui, P., Chen, Y., Mustafa, R., Ba, X., et al. (2012). Comparative geno-plasticity analysis of Mycoplasma bovis HB0801 (Chinese isolate). PLoS One 7:e38239. doi: 10.1371/journal.pone.0038239

Qin, L., Chen, Y., and You, X. (2019). Subversion of the immune response by human pathogenic mycoplasmas. Front. Microbiol. 10:1934. doi: 10.3389/ fmicb.2019.01934

Rasheed, M. A., Qi, J., Zhu, X., Chenfei, H., Menghwar, H., Khan, F. A., et al. (2017). Comparative genomics of Mycoplasma bovis strains reveals that decreased virulence with increasing passages might correlate with potential virulencerelated factors. Front. Cell. Infect. Microbiol. 7:177. doi: 10.3389/fcimb.2017.00177

Razin, S., and Knight, B. C. (1960). The effects of ribonucleic acid and deoxyribonucleic acid on the growth of myeoplasma. J. Gen. Microbiol. 22, 504-519. doi: 10.1099/00221287-22-2-504

Razin, S., Yogev, D., and Naot, Y. (1998). Molecular biology and pathogenicity of mycoplasmas. Microbiol. Mol. Biol. Rev. 62, 1094-1156.

Rottem, S. (2003). Interaction of mycoplasmas with host cells. Physiol. Rev. 83, 417-432. doi: 10.1152/physrev.00030.2002 
Schmidt, J. A., Browning, G. F., and Markham, P. F. (2007). Mycoplasma hyopneumoniae mhp379 is a Ca2+-dependent, sugar-nonspecific exonuclease exposed on the cell surface. J. Bacteriol. 189, 3414-3424. doi: 10.1128/ JB.01835-06

Schumacher, M., Nicholson, P., Stoffel, M. H., Chandran, S., D’Mello, A., Ma, L., et al. (2019). Evidence for the cytoplasmic localization of the L- $\alpha$ glycerophosphate oxidase in members of the "Mycoplasma mycoides cluster". Front. Microbiol. 10:1344. doi: 10.3389/fmicb.2019.01344

Sharma, S., Tivendale, K. A., Markham, P. F., and Browning, G. F. (2015). Disruption of the membrane nuclease gene (MBOVPG45_0215) of Mycoplasma bovis greatly reduces cellular nuclease activity. J. Bacteriol. 197, 1549-1558. doi: 10.1128/JB.00034-15

Simpson, J. T., Wong, K., Jackman, S. D., Schein, J. E., Jones, S. J. M., and Birol, I. (2009). ABySS: a parallel assembler for short read sequence data. Genome Res. 19, 1117-1123. doi: 10.1101/gr.089532.108

Skapski, A., Hygonenq, M.-C., Sagné, E., Guiral, S., Citti, C., and Baranowski, E. (2011). Genome-scale analysis of Mycoplasma agalactiae loci involved in interaction with host cells. PLoS One 6:e25291. doi: 10.1371/journal. pone.0025291

Somarajan, S. R., Kannan, T. R., and Baseman, J. B. (2010). Mycoplasma pneumoniae Mpn133 is a cytotoxic nuclease with a glutamic acid-, lysine- and serine-rich region essential for binding and internalization but not enzymatic activity. Cell. Microbiol. 12, 1821-1831. doi: 10.1111/j.1462-5822.2010.01513.x

Szczepanek, S. M., Boccaccio, M., Pflaum, K., Liao, X., and Geary, S. J. (2014). Hydrogen peroxide production from glycerol metabolism is dispensable for virulence of Mycoplasma gallisepticum in the tracheas of chickens. Infect. Immun. 82, 4915-4920. doi: 10.1128/IAI.02208-14

Szczepanek, S. M., Frasca, S., Schumacher, V. L., Liao, X., Padula, M., Djordjevic, S. P., et al. (2010). Identification of lipoprotein MslA as a neoteric virulence factor of Mycoplasma gallisepticum. Infect. Immun. 78, 3475-3483. doi: 10.1128/ IAI.00154-10

van Kuppeveld, F. J., van der Logt, J. T., Angulo, A. F., van Zoest, M. J., Quint, W. G., Niesters, H. G., et al. (1992). Genus- and species-specific identification of mycoplasmas by $16 \mathrm{~S}$ rRNA amplification. Appl. Environ. Microbiol. 58, 2606-2615.

Vilei, E. M., and Frey, J. (2001). Genetic and biochemical characterization of glycerol uptake in Mycoplasma mycoides subsp. mycoides SC: its impact on $\mathrm{H}(2) \mathrm{O}(2)$ production and virulence. Clin. Diagn. Lab. Immunol. 8, 85-92. doi: 10.1128/CDLI.8.1.85-92.2001

Vlassov, V. V., Laktionov, P. P., and Rykova, E. Y. (2007). Extracellular nucleic acids. BioEssays 29, 654-667. doi: 10.1002/bies.20604
Vorkapic, D., Pressler, K., and Schild, S. (2016). Multifaceted roles of extracellular DNA in bacterial physiology. Curr. Genet. 62, 71-79. doi: 10.1007/ s00294-015-0514-X

Wise, K. S., Calcutt, M. J., Foecking, M. F., Röske, K., Madupu, R., and Methé, B. A. (2011). Complete genome sequence of Mycoplasma bovis type strain PG45 (ATCC 25523). Infect. Immun. 79, 982-983. doi: 10.1128/IAI.00726-10

Xu, J., Teng, D., Jiang, F., Zhang, Y., El-Ashram, S. A., Wang, H., et al. (2015). Mycoplasma gallisepticum MGA_0676 is a membrane-associated cytotoxic nuclease with a staphylococcal nuclease region essential for nuclear translocation and apoptosis induction in chicken cells. Appl. Microbiol. Biotechnol. 99, 1859-1871. doi: 10.1007/s00253-014-6185-6

Yacoub, E., and Mardassi, B. (2016). Mm19, a mycoplasma meleagridis major surface nuclease that is related to the RE_AlwI superfamily of endonucleases. PLoS One 11:e0152171. doi: 10.1371/journal.pone.0152171

Yamamoto, T., Kida, Y., Sakamoto, Y., and Kuwano, K. (2017). Mpn491, a secreted nuclease of Mycoplasma pneumoniae, plays a critical role in evading killing by neutrophil extracellular traps. Cell. Microbiol. 19:e12666. doi: 10.1111/cmi.12666

Zhang, R., Han, X., Chen, Y., Mustafa, R., Qi, J., Chen, X., et al. (2014). Attenuated Mycoplasma bovis strains provide protection against virulent infection in calves. Vaccine 32, 3107-3114. doi: 10.1016/j.vaccine.2013.12.004

Zhang, H., Zhao, G., Guo, Y., Menghwar, H., Chen, Y., Chen, H., et al. (2016). Mycoplasma bovis MBOV_RS02825 encodes a secretory nuclease associated with cytotoxicity. Int. J. Mol. Sci. 17, pii: E628. doi: 10.3390/ijms17050628

Zhao, G., Zhang, H., Chen, X., Zhu, X., Guo, Y., He, C., et al. (2017). Mycoplasma bovis NADH oxidase functions as both a NADH oxidizing and $\mathrm{O}_{2}$ reducing enzyme and an adhesin. Sci. Rep. 7:44. doi: 10.1038/s41598-017-00121-y

Zimmerman, C.-U., and Herrmann, R. (2005). Synthesis of a small, cysteinerich, 29 amino acids long peptide in Mycoplasma pneumoniae. FEMS Microbiol. Lett. 253, 315-321. doi: 10.1016/j.femsle.2005.09.054

Conflict of Interest: The authors declare that the research was conducted in the absence of any commercial or financial relationships that could be construed as a potential conflict of interest.

Copyright (c) 2019 Zhu, Dordet-Frisoni, Gillard, Ba, Hygonenq, Sagné, Nouvel, Maillard, Assié, Guo, Citti and Baranowski. This is an open-access article distributed under the terms of the Creative Commons Attribution License (CC BY). The use, distribution or reproduction in other forums is permitted, provided the original author(s) and the copyright owner(s) are credited and that the original publication in this journal is cited, in accordance with accepted academic practice. No use, distribution or reproduction is permitted which does not comply with these terms. 